\title{
Методика гібридної реваскуляризації міокарда у пацієнтів 3 атеросклеротичним ураженням коронарних судин
}

\author{
Габрієлян А. В., Доманський Т. М., Береговой О. В.
}

ДУ «Національний інститут хірургії та трансплантології імені О. О. Шалімова НАМН» (Київ)

\begin{abstract}
Мета - оцінити ефективність і безпечність повної реваскуляризації міокарда у пацієнтів з ішемічною хворобою серця та багатосудинним ураженням коронарного русла шляхом поєднання різних методик РСI та CABG.

Матеріали та методи. Проведено дослідження 26 пацієнтів, яким виконана повна реваскуляризація міокарда шляхом поєднання традиційних методик: черезшкірного коронарного втручання (PCI) та коронарного шунтування без апарата штучного кровообігу (CABG OFF PUMP). Усі пацієнти в анамнезі мали інфаркт, багатосудинне ураження коронарних артерій (КА) та різний функціональний клас стенокардії.

Результати та обговорення. В ранній післяопераційний період (до 30 діб) не виявили у групі жодних ускладнень. У 8 пацієнтів спостерігалася підвищена післяопераційна ексудація. Аритмогенні ускладнення у вигляді пароксизмів фібриляції передсердь були у 4 пацієнтів. В усіх пацієнтів після другого етапу PCI використовувався пристрій для закриття місця пункції стегнової артерії Angio-Seal.

Висновки. Отримані безпосередні та середньострокові результати свідчать про ефективність і безпечність такого підходу.
\end{abstract}

Ключові слова: реваскуляризація міокарда, гібридна методика, коронарне шунтування.

Пацієнти з багатосудинним ураженням коронарних артерій (KА) часто мають стабільну або нестабільну стенокардію [1]. Зазвичай таким пацієнтам показана реваскуляризація міокарда з використанням традиційних методик черезшкірного коронарного втручання (PCI) або коронарне шунтування (CABG). Проте не завжди можливо виконати повну реваскуляризацію однією з методик. Цьому перешкоджає низка факторів - таких, як анатомо-топографічна особливість судин міокарда або їх діаметр і характер ураження атеросклеротичними бляшками.

Проведений мета-аналіз рандомізованих 28 досліджень Zimarino М. та співавт. мав на меті перевірити, чи забезпечує стратегія повної реваскуляризації міокарда (ПРМ) порівняно з неповною реваскуляризацією міокарда (НРМ) (як із черезшкірними коронарними втручаннями, так і з коронарним артеріальним шунтуванням) клінічну перевагу в пацієнтів із багатосудинним захворюванням коронарних артерій (MVCAD). Результати дослідження 83695 пацієнтів свідчать, що у групі пацієнтів, яким була виконана ПРМ за методикою PCI та CABG, рівень смертності нижчий, ніж у групі пацієнтів, яким була виконана НРМ. Так само ризик IM та повторної реваскуляризації нижчий у пацієнтів із ПРМ проти НРМ [2].

В одноцентровому проспективному груповому дослідженні послідовних пацієнтів із багатосудинним ураженням коронарних артерій, яким проводи- лося стентування коронарних артерії стентами з лікарським покриттям (drug-eluting stent DES) із січня 2003 р. по грудень 2013 р., Chang та спів. [3] порівнювали результати з аналогічними у пацієнтів, яким була виконана ПРМ проти НРМ. Дослідники продемонстрували, що не було суттєвої різниці у смертності від усіх причин, а також у відсотку інсульту та необхідності повторної реваскуляризації; в той час як ризик гострого інфаркту міокарда (IM) при спостереженні був вищим у тих пацієнтів, що мали НРМ проти ПРМ.

Питання про те, чи потрібно виконувати повну реваскуляризацію міокарда всіма можливими методами чи можна обмежитися «достатньою» реваскуляризацією, продовжує обговорюватися $[1,4,5]$.

Мета - оцінити ефективність і безпечність повної реваскуляризації міокарда у пацієнтів 3 ішемічною хворобою серця та багатосудинним ураженням коронарного русла шляхом поєднання різних методик РСI та CABG.

Матеріали та методи. Проведено ретроспективний аналіз результатів лікування пацієнтів 3 ішемічною хворобою серця та багатосудинним ураженням KA. Прооперовано 26 пацієнтів з ішемічною хворобою серця: жінок - 14, чоловіків - 12. Середній вік складав $61,0 \pm 9,6$. Цукровий діабет II типу виявлено

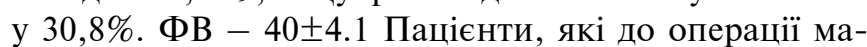
ли 1, 2 та 3 інфаркти в анамнезі, становили 50\% (13), 


\section{Таблиця 1}

Доопераційна характеристика пацієнтів

у досліджуваній групі

\begin{tabular}{|c|c|c|c|c|c|c|}
\hline & \multicolumn{3}{|c|}{ Інфаркт в анамнезі } & \multirow{2}{*}{$\begin{array}{l}\text { Нестабільна } \\
\text { стенокардія }\end{array}$} & \multirow[b]{2}{*}{ ФK III-IV } & \multirow[b]{2}{*}{ ФК I-I } \\
\hline & 1 & 2 & 3 і більше & & & \\
\hline Чол. & 5 & 5 & 2 & 3 & 4 & 8 \\
\hline Жін. & 8 & 4 & 2 & 4 & 3 & 11 \\
\hline
\end{tabular}

$34,6 \%$ (9) та 15,4\% (4) відповідно. 3 нестабільною стенокардією були 26,9\% (7), стабільну стенокардію I-II та III-IV класу мали 26,9\% (7) та 73,1\% (19) пацієнтів (табл. 1).

За характером ураження коронарних судин пацієнти групи розподілялися таким чином: у 19 пацієнтів уражено 2 KA, у 6 пацієнтів - 3 KA, в 1 пацієнта 4 КА. Відсоткове співвідношення зображено на рис. 1 .

Методика виконання реваскуляризації. Перший етап - CABG off-pump, шунтування 1, 2 або 3 вінцевих артерій. (табл. 2). Наступним етапом в ранньому післяопераційному періоді виконувалося РСІ.

Результати та обговорення. Пацієнти, яким виконувалася реваскуляризація міокарда із застосуванням гібридної методики, мали багатосудинне ураження. Особливість ураження коронарних артерій, їх анатомічна будова та діаметр не дозволяли виконати повну реваскуляризацію міокарда лише одним із методів. Усі пацієнти прооперовані без використання апарата штучного кровообігу. У групі пацієнтів, які мали ураження двох коронарних артерій, одна 3 яких LAD, операція виконувалася за міні-інвазивною методикою - MIDCAB. Це дозволило виконати шунтування та стентування КА в один день. Решта 13 пацієнтів цієї групи оперувалися з доступу серединної стернотомії, що було пов'язано з нестабільним станом пацієнтів. В одного пацієнта із двосудинним ураженням LIMA використовувалася в якості шунта для згинаючої гілки лівої коронарної артерії, a LAD була стентована. У групі пацієнтів із двосудинним ураженням (19 пацієнтів) на одного пацієнта використано 1 шунт та 1 стент (19 артеріальних шунтів і

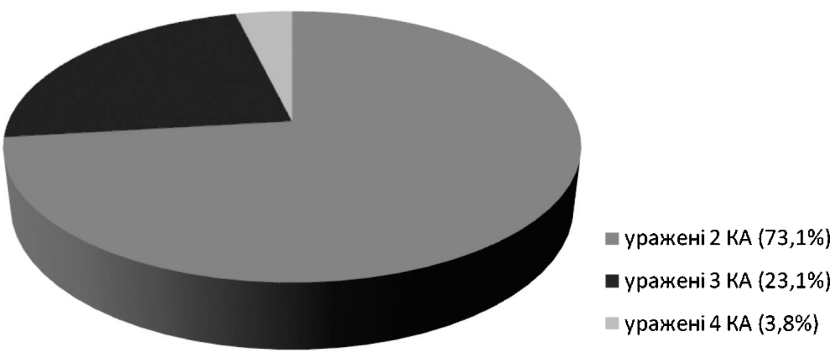

Рис. 1. Відсоткове співвідношення за характером ураження КА у групі
Таблиця 2

Гібридна реваскуляризація

\begin{tabular}{|c|c|c|}
\hline Обсяг оперативного втручання & $\begin{array}{l}\text { Кількість } \\
\text { пацієнтів }\end{array}$ & $\begin{array}{c}\text { Часовий } \\
\text { інтервал } \\
\text { між про- } \\
\text { цедурами } \\
\text { (год.) }\end{array}$ \\
\hline $\begin{array}{l}\text { MIDCAB LIMA } \rightarrow \text { LAD (міні-інвазивне } \\
\text { коронарне шунтування) + PCI non } \\
\text { LAD (стентування коронарної артерії } \\
\text { non LAD) }\end{array}$ & 5 & $3-5$ \\
\hline $\begin{array}{l}\text { CABG } 2 \text { (коронарне шунтування 2) } \\
+ \text { PCI LAD (стентування коронарної } \\
\text { артерії LAD) }\end{array}$ & 5 & $48-56$ \\
\hline $\begin{array}{l}\text { CABG } 1 \text { LIMA } \rightarrow \text { LAD (мамарокоро- } \\
\text { нарне шунтування LAD) + PCI non } \\
\text { LAD (стентування коронарної артерії } \\
\text { non LAD) }\end{array}$ & 13 & $48-56$ \\
\hline $\begin{array}{l}\text { CABG } 1 \text { LIMA } \rightarrow \text { non LAD (мамароко- } \\
\text { ронарне шунтування non LAD) + PCI } \\
\text { LAD (стентування коронарної артерії } \\
\text { LAD) }\end{array}$ & 1 & $48-56$ \\
\hline $\begin{array}{l}\text { CABG } 3 \text { (коронарне шунтування 3) } \\
+ \text { PCI LAD (стентування коронарної } \\
\text { артерії LAD) }\end{array}$ & 1 & $48-56$ \\
\hline $\begin{array}{l}\text { CABG } 2 \text { LIMA } \rightarrow \text { LAD (мамарокоро- } \\
\text { нарне шунтування LAD, аортокоро- } \\
\text { нарне шунтування) + PCI non LAD }\end{array}$ & 1 & $48-56$ \\
\hline
\end{tabular}
(стентування коронарної артерії non LAD)

19 drug-eluting stent). Трьом паціснтам виконано шунтування ПКА, двом - ОГ ЛКА та стентували LAD. Анастомоз LIMA $\rightarrow$ LAD та стент в ОГ або ПКА виконано у 13 пацієнтів, в одного пацієнта - LIMA $\rightarrow$ ОГ та стент у ПКА.

Другу групу становили 6 пацієнтів із трисудинним ураженням. Доступ - серединна стернотомія. Методика CABG off-pump. П'ятьом пацієнтам цієї групи виконано аортокоронарне шунтування 3 використанням аутовени та стентування LAD. Одному пацієнту із цієї групи виконано мамарокоронарне шунтування LAD, аортокоронарне шунтування та стентування коронарної артерії. В цій групі (6 пацієнтів) на одного пацієнта використано 2 шунти та 1 стент (11 аутовенозних шунтів, 1 артеріальний шунт та 6 drug-eluting stent).

Одному пацієнту з багатосудинним ураженням виконано аортокоронарне шунтування з використанням аутовени та стентування LAD. На одного пацієнта використано 3 шунти та 1 стент (3 аутовенозні шунти, 1 drug-eluting stent).

У ранній після операційний період (до 30 діб) не виявили у групі жодних ускладнень. У 8 пацієнтів спостерігалася підвищена післяопераційна ексудація, та шестеро пацієнтів потребували гемотрансфузії в реані- 


\section{Таблиця 3}

Основні несприятливі події протягом 30 днів

\begin{tabular}{lc} 
Види ускладнень & (n=26) \\
\hline - кровотеча в п/о періоді & $30.76 \%(8)$ \\
\hline - гемотрансфузія & $23.07 \%(6)$ \\
\hline - велика аритмія & $15.38 \%(4)$ \\
\hline - пролонгована інкубація (>48 годин) & $0 \%$
\end{tabular}

маційному періоді. Це пов'язано з виконанням оперативного втручання на фоні прийому дезагрегантної та антикоагулянтної терапії.

Аритмогенні ускладнення у вигляді пароксизмів фібриляції передсердь були у 4 пацієнтів та купувалися внутрішньовенним введенням аміодарону в дозі 5 мг/кг маси тіла у 250 мл 5\% розчину глюкози з використанням електронної помпи. Напади купирувалися протягом першої доби раннього післяопераційного періоду і в жодному випадку не потребували проведення електричної деполяризації.

Зважаючи на подвійний прийом дезагрегантної терапії в усіх пацієнтів, після другого етапу РСІ використовувався пристрій для закриття місця пункції стегнової артерії Angio-Seal. Середня тривалість перебування у клініці становила $9 \pm 2$ діб. Протягом першого року після операції в даній групі не спостерігалося ускладнень, що потребували б повторної госпіталізації або проведення коронарографії (табл. 3).

Висновки. Поєднання операції off-pump КШ і РCI дозволяє виконати повну реваскуляризацію міокарда з максимальним ефектом при мінімальному втручанні i $€$ ще одним методом вибору в лікуванні пацієнтів із багатосудинним ураженням. Отримані перспективні ранні та середньострокові результати показали достатню ефективність і безпеку такого підходу. Показання, терміни, послідовність і техніка виконання процедур подальшого дослідження.

\section{Література}

1. Complete versus incomplete coronary revascularization of patients with multivessel coronary artery disease / Sandoval Y., Brilakis E. S., Canoniero M. et al. // Curr Treat Options Cardiovasc Med. - 2015. - Vol. 17. P. 366. doi: 10.1007/s11936-015-0366-1

2. A meta-analysis of randomized and observational studies / Marco Zimarino MD, PhD, Fabrizio Ricci MD, Mattia Romanello MD et al. // Catheter Cardiovasc Interventions. - 2016 Jan 1. - Vol. 87 (1). - P. 3-12. DOI: $10.1002 / \mathrm{ccd} .25923$

3. Complete versus incomplete revascularization in patients with multivessel coronary artery disease treated with drugeluting stents / Chang M., Ahn J. M., Kim N. et al. // Am Heart J. - 2016. - Vol. 179. - P. 157-65. Doi: 10.1016/j. ahj.2016.06.020

4. OngA.T., Serruys P.W.Complete revascularization: coronary artery bypass graft surgery versus percutaneous coronary intervention // Circulation. - 2006. - Vol. 114. - P. 24955. DOI:10.1161/CIRCULATIONAHA. 106.614420

5. Complete versus incomplete coronary revascularization of patients with multivessel coronary artery disease / Sandoval Y., Brilakis E. S., Canoniero M. et al. // Curr Treat Options Cardiovasc Med. - 2015. - Vol. 17. - P. 366. Doi: $10.1007 / \mathrm{s} 11936-015-0366-1$.

\title{
Method of hybrid revascularization of miocard in patients with atherosclerotic damage of coronary vessels
}

\author{
Gabrielyan A., Domanskyy T., Beregovoy O. \\ National Institute of Surgery and Transplantatology by O. Shalimov NAMS of Ukraine (Kyiv)
}

Goal - to evaluate the efficacy and safety of total revascularization of cardiac muscle in patients with ischemic heart disease and multivessel coronary disease by combination of different methods of PCI and CABG.

Materials and methods. The study included 26 patients that underwent total revascularization of myocardium by combination of the traditional methods of PCI and CABG OFF PUMP. All patients had myocardial infarction in past, multivessel coronary disease and had different classes of stenocardia.

Results and discussion. There weren't any complications in early postoperative period (30 days after operation). 8 patients had extended postoperative exudation. Arrhythmogenic complications such as atrial fibrillation had 4 patients. After second stage of PCI special device for femoral artery closure Angio Seal was used in all patients.

Conclusions. The results of study confirm that these methods are effective and safe.

Key words: myocardium revascularization, hybrid method, $C A B G$. 
Габрієлян А. В. / Методика гібридної реваскуляризації міокарда у пацієнтів з атеросклеротичним ураженням...

\title{
Методика гибридной реваскуляризации миокарда у пациентов с атеросклеротическим поражением коронарных сосудов
}

\author{
Габриелян А. В., Доманский Т. Н., Береговой О. В. \\ ГУ «Национальный институт хирургии и трансплантологии имени А. А. Шалимова НАМН» (Киев)
}

Цель - оценить эффективность и безопасность полной реваскуляризации миокарда у пациентов с ишемической болезнью сердца и многочисленными поражениями коронарного русла путем объединения различных методик РСI и САВG.

Материалы и методы. В исследование вошли 26 пациентов, которым была проведена полная реваскуляризация миокарда путем объединения традиционных методик: чрескожного коронарного вмешательства (PCI) и коронарного шунтирования без аппарата искусственного кровообрашения (CABG OFF PUMP). У всех пациентов в анамнезе был инфаркт миокарда, мультисосудистое поражение коронарных артерий (КА) и разный функциональный класс стенокардии.

Результаты и обсуждение. В течение раннего послеоперационного периода (до 30 суток) в группе не было обнаружено никаких осложнений. У 8 пациентов наблюдалась повышенная послеоперационная экссудация. Аритмогенные осложнения в виде пароксизмов фибрилляций предсердий были у 4 пациентов. У всех пациентов после второго этапа PCI использовалось устройство для закрытия места пункции бедренной apтерии Angio-Seal.

Выводы. Полученные непосредственные и среднесрочные результаты свидетельствуют об эффективности и безопасности этого подхода.

Ключевые слова: реваскуляризация миокарда, гибридная методика, коронарное шунтирование. 